\title{
HUBUNGAN KARAKTERISTIK INDIVIDU DAN IKLIM KERJA DENGAN KELUHAN MSDS PADA PEKERJA PERAKITAN MINI BUS DI PT MEKAR ARMADA JAYA MAGELANG
}

\author{
Komarul Fausiyah \\ Tata Guna Patria Consultant \\ Plaza Golden Fatmawati (D’ best) Blok J 8 \\ Jl. RS Fatmawati 15, Jakarta 12420 \\ Email:kfausiyah@gmail.com
}

\begin{abstract}
Musculoskeletal disorders (MSDs) are disturbances in the skeletal muscles that affect workers, ranging from mild to very severe complaints. MSDs complaints can be caused by internal factor such as gender, age, years of employment, smoking habit and external factor such as exposure to hot work climates. These was an analytical-observational study with a cross-sectional approach. The research samples consisted of 65 workers. Samples were selected by simple random sampling. Individual characteristics data collected by questionnaire, work climates data were obtained by Wet Bulb Globe Temperature (WBGT) measurement and MSDs complaints data were analyzed by Nordic Body Map (NBM). All data were analyzed by the Spearman-rho correlation with a significance level of $\alpha=0.05$. Results showed that most of workers had a moderate risk of MSDs complaints (55.4\%). Based on WBGT measurement, work climate exceeded the Threshold Limit Value (TLV). There were no correlation between MSDs complaints and workers characteristics (age, years of employment, and smoking habits). However, there was a significant correlation between MSDs complaints and work climate ( $p=0.000$; $r=0.730)$. The company are advised to redesign natural and artificial ventilation system, increasing the knowledge of all workers about ergonomic risks prevention based on their activities, reduce the health effects of workers smoking habit by regular exercise every day and set time of job rotation for 5-15 minutes/hour for workers do other work with a lighter workload.
\end{abstract}

Keywords: individual characteristics, work climate, MSDs complaints

\begin{abstract}
ABSTRAK
Muskuloskeletal disorders (MSDs) adalah gangguan pada otot-otot skeletal yang dirasakan seseorang mulai dari keluhan yang ringan sampai dengan sangat berat. Keluhan MSDs bisa disebabkan oleh faktor internal seperti umur, masa kerja, kebiasaan merokok dan faktor eksternal seperti paparan iklim kerja panas. Penelitian ini termasuk observasional analitik dengan pendekatan cross sectional. Sampel penelitian adalah 65 pekerja. Pengambilan sampel menggunakan teknik simple random sampling. Data karakteristik individu dikumpulkan melalui pembagian kuesioner, data iklim kerja diperoleh melalui pengukuran Indeks Suhu Basa dan Bola (ISBB), dan data keluhan MSDs dianalisis menggunakan metode Nordic Body Map (NBM). Analisis data menggunakan uji korelasi Spearman-rho dengan tingkat signifikansi $\alpha=0,05$. Hasil penelitian menunjukkan bahwa sebagian besar pekerja mengalami keluhan MSDs tingkat risiko sedang $(55,4)$. Berdasarkan hasil pengukuran ISBB, paparan iklim kerja melebihi nilai ambang batas (NAB). Hasil penelitian menunjukkan bahwa tidak ada hubungan antara keluhan MSDs dengan karakteristik individu (umur, masa kerja dan kebiasaan merokok) tetapi ada hubungan yang signifikan dan kuat antara paparan iklim kerja dan keluhan MSDs ( $p=$ $0,000 ; r=0,730)$. Perusahaan disarankan untuk mendesain ulang sistem ventilasi alami dan buatan di bagian perakitan mini bus, meningkatkan pengetahuan pekerja tentang pencegahan risiko-risiko ergonomi berdasarkan aktivitas kerjanya masing-masing, mengurangi dampak kesehatan dari kebiasaan merokok pekerja melalui senam rutin setiap pagi dan menetapkan waktu rotasi kerja selama 5-15 menit/jam untuk pekerja melakukan pekerjaan lain di luar pekerjaannya dengan beban kerja yang lebih ringan.
\end{abstract}

Kata kunci: karakteristik individu, iklim kerja, keluhan MSDs

\section{PENDAHULUAN}

Salah satu penyakit akibat hubungan kerja (PAHK) yang disebabkan karena faktor ergonomi adalah musculoskeletal disorders (MSDs). Kasus
MSDs adalah masalah yang paling banyak ditemui di tempat kerja pada sebagian besar negara-negara industri di dunia (Sanders, 2004). MSDs juga merupakan alasan kedua terbanyak bagi para pekerja 
industri untuk memutuskan pensiun dini (Oborne, 1995). Kasus MSDs lebih sering disebabkan karena ketidaksesuaian antara peralatan, manusia dan proses kerja sehingga manusia harus melakukan pekerjaannya dengan posisi-posisi yang tidak natural dan ergonomis (Tarwaka, 2015).

MSDs bisa terjadi dalam kurun waktu yang panjang (mingguan, bulanan bahkan tahunan) dan seringkali baru terdeteksi ketika sudah pada tahap parah (kronis) sehingga pekerja tidak bisa mendapatkan kesembuhan total (Suma'mur, 2009).

MSDs pada umumnya dihasilkan dari paparan berbagai faktor risiko yang dapat memperburuk gangguan, bukan dari satu aktivitas atau trauma tertentu saja seperti terjatuh, terbentur sesuatu atau terkilir. MSDs juga dapat menyebabkan sejumlah kondisi seperti nyeri, mati rasa, kesemutan, kaku sendi, kehilangan keseimbangan otot, kesulitan bergerak, hingga kelumpuhan (Hales et al, 1994).

Bekerja dalam waktu yang lama dengan posisi statis baik berdiri ataupun duduk, menimbulkan ketidaknyamanan. Posisi kerja berdiri membuat pekerja selalu berusaha untuk menyeimbangkan posisi tubuhnya sehingga menimbulkan beban kerja statis pada otot-otot punggung dan kaki. Posisi kerja duduk dalam waktu yang lama dan berulang dapat menyebabkan melembeknya otot-otot perut, gangguan organ pencernaan hingga melengkungnya tulang belakang (Pangaribuan, 2009).

Gangguan MSDs bisa terjadi pada seluruh anggota tubuh baik skeletal bagian atas seperti leher, punggung, bahu dan pinggang serta bagian bawah seperti kaki, paha, lutut dan betis tergantung dari bagian-bagian tubuh yang mendapat tekanan akibat posisi-posisi kerja tidak ergonomis (Susila, 2002).

Musculoskeletal Disorders (MSDs) dipengaruhi oleh beberapa faktor yang dapat di kelompokkan menjadi dua, yaitu faktor internal dan faktor eksternal. Faktor internal adalah faktor yang ada dalam diri pekerja dan tidak berhubungan langsung dengan pekerjaannya seperti umur, jenis kelamin, masa kerja, kebiasaan merokok, kesegaran jasmani dan indeks masa tubuh. Faktor eksternal adalah faktor di luar diri pekerja dan berhubungan langsung dengan pekerjaannya seperti posisi kerja tidak alamiah, shift kerja, getaran, tekanan dan iklim kerja (Tarwaka, 2015).

Chaffin (1979) dan Guo et al (1995) meneliti bahwa keluhan musculoskeletal mulai dirasakan saat pekerja berumur 25-65 tahun. Keluhan pertama dirasakan saat pekerja berusia 35 tahun dan keparahannya akan meningkat seiring bertambahnya umur. Penelitian yang telah dilakukan oleh Battie et al (1989) menjelaskan bahwa kekuatan otot maksimal manusia terjadi pada umur 20-29 tahun, untuk selebihnya kekuatan otot akan mengalami penurunan.

Masa kerja merupakan faktor risiko kombinasi yang dapat mempengaruhi seorang untuk mengalami keluhan MSDs, terutama jika pekerjaan yang dilakukan membutuhkan pengerahan otot dan tenaga yang besar selama bekerja (Battie et al., 1989).

Peningkatan konsumsi rokok pada pekerja (khusunya jika membutuhkan pengerahan otot selama bekerja) akan semakin menurunkan fungsi paru-paru untuk memasok oksigen yang dibutuhkan dalam proses pembakaran karbohidrat, sehingga akan terjadi penumpukan asam laktat yang akan memicu timbulnya nyeri otot pada pekerja (Suma'mur, 2009).

Iklim kerja pada bagian perakitan body kendaraan PT Mekar Armada Jaya Magelang tergolong kurang baik. Paparan panas banyak dihasilkan dari aktivitas pengelasan yang terjadi terus menerus saat proses perakitan, sedangkan ventilasi alami dan buatan yang tersedia kurang memadai (Fausiyah, 2016).

Perbedaan suhu lingkungan dan tubuh yang terlalu signifikan bisa menyebabkan sebagian energi yang ada dalam tubuh terkuras untuk beradaptasi dengan kondisi tersebut. Kekurangan energi yang terjadi dapat menimbulkan rasa nyeri otot akibat proses metabolisme karbohidrat yang terhambat dan menyebabkan terjadinya penimbunan asam laktat pada otot. Penimbunan asam laktat yang berlebihan menyebakan kaku dan/atau nyeri pada otot. Jika kondisi ini terjadi berulang dalam waktu lama, akan menyebabkan gangguan MSDs pada pekerja (Tarwaka, 2015).

PT Mekar Armada Jaya Magelang merupakan salah satu perusahaan karoseri terbesar di Indonesia. Aktivitas utamanya adalah perakitan body kendaraan roda empat atau lebih seperti bus, mini bus, pick up, heavy duty truck, dan lainnya. Aktivitas kerja di bagian perakitan body kendaraan seringkali menuntut sebagian besar pekerja untuk bekerja secara manual (manual handling) dan mengambil posisi kerja yang kurang ergonomis.

Penilaian keluhan MSDs dan tingkat keparahan yang dirasakan pekerja dapat dilakukan dengan menggunakan metode NBM. Lembar kuesioner NBM dapat menjelaskan bagian otot mana yang mengalami keluhan. Tingkat keluhan yang dirasakan pekerja mulai dari rendah (tidak ada keluhan/cidera) 
hingga tinggi (keluhan sangat sakit). Pengumpulan data keluhan MSDs lebih efektif dilakukan saat hari kerja untuk menilai pengaruh paparan di tempat kerja (Tarwaka, 2015).

Berdasarkan hasil observasi, semua pekerja bagian perakitan mini bus berjenis kelamin laki-laki. Sebagian besar pekerja merupakan perokok dengan masa kerja yang bervariasi. PT Mekar Armada Jaya Magelang belum pernah melakukan pemeriksaan kesehatan terkait gangguan skeletal pada pekerja ataupun memberikan pelatihan terkait faktorfaktor risiko dan pencegahan MSDs. Perusahaan juga belum pernah melakukan identifikasi terhadap masalah-masalah ergonomi yang dirasakan pekerja, sehingga perlu dilakukan analisis awal keluhan MSDs yang dirasakan oleh pekerja.

Tujuan umum penelitian adalah untuk menganalisis hubungan antara karakteristik individu dan iklim kerja dengan keluhan MSDs pada pekerja bagian perakitan mini bus di PT Mekar Armada Jaya Magelang. Tujuan khususnya adalah melakukan analisis iklim kerja melalui pengukuran ISBB, menilai keluhan MSDs dengan metode NBM, menganalisis kuat tidaknya hubungan antara karakteristik individu dan iklim kerja dengan keluhan MSDs pada pekerja.

\section{METODE}

Penelitian ini termasuk observasional analitik dengan desain cross-sectional. Penelitian dilaksanakan pada bulan Mei-November 2016 di bagian perakitan mini bus PT Mekar Armada Jaya Magelang.

Populasi penelitian adalah seluruh pekerja bagian perakitan mini bus. Jumlah sampel adalah 65 orang yang ditentukan menggunakan teknik simple random sampling. Penelitian menetapkan kriteria ekslusi yaitu pekerja yang tidak ada riwayat penyakit reumatik atau gangguan otot dan tulang selama bekerja. Informasi mengenai ada tidaknya riwayat penyakit reumatik atau gangguan otot dan tulang bukan berdasarkan pada catatan medis (hasil rekam medis) pekerja tetapi melalui wawancara sebelum pembagian kuesioner dilakukan. Kondisi ini adalah salah satu keterbatasan dalam penelitian.

Data yang dikumpulkan adalah data primer dan sekunder. Data primer didapat melalui observasi, pengukuran iklim kerja dan pengisian kuesioner. Data karakteristik individu diperoleh melalui pembagian kuesioner. Data iklim kerja diperoleh melalui pengukuran ISBB (indeks suhu basah dan bola) sebanyak 3 kali yaitu pada pagi hari (awal bekerja), siang dan sore hari (sebelum pulang). Data keluhan MSDs didapat melalui pembagian kuesioner NBM Pengukuran keluhan MSDs dilakukan 1x selama bekerja yaitu pada jam istirahat (setelah bekerja). Tingkat keluhan MSDs dinilai menggunakan 4 skala likert dengan kriteria sebagai berikut (Tarwaka, 2015): Skor 0 = tidak ada keluhan/ rasa nyeri otot sama sekali (tidak sakit), Skor $1=$ ada sedikit keluhan/nyeri pada otot tetapi belum mengganggu pekerjaan (sedikit sakit), Skor 2 = ada keluhan/nyeri pada otot dan sudah mengganggu pekerjaan tetapi segera hilang setelah dilakukan istirahat (sakit), Skor $3=$ Ada keluhan sangat sakit pada bagian otot dan rasa sakit itu tidak segera hilang walaupun sudah beristirahat lama (sakit sekali)

Variabel independen penelitian ini adalah karakteristik individu dan iklim kerja, sedangkan variabel dependennya adalah keluhan MSDs. Analisis data yang digunakan untuk menganalisis hubungan antara 2 variabel adalah uji korelasi spearman-rho.

\section{HASIL}

\section{Gambaran Umum Bagian Perakitan Mini Bus di PT Mekar Armada Jaya Magelang}

Perakitan mini bus adalah salah satu bagian/unit kerja yang memiliki target produksi cukup tinggi. Jumlah total tenaga kerjanya adalah 192 orang dan seluruhnya adalah laki-laki. Sebagian besar aktivitas kerja di unit kerja ini menghasilkan bising dan panas yang cukup tinggi. Paparan kebisingan berasal dari mesin-mesin kerja manual seperti alat las, mesin cutting, gerinda, mesin press dan alat tangan lainnya (palu, pengungkit). Paparan panas berasal dari aktivitas pengelasan yang cukup tinggi dan diperparah oleh sistem ventilasi udara yang kurang baik.

Aktivitas kerja bagian perakitan mini bus terbagi menjadi 8 pos berdasarkan sub-sub kegiatan kerja pada masing-masing pos. Jenis pekerjaan di bagian perakitan mini bus cukup bervariasi sehingga posisi-posisi kerja yang dilakukan pekerja juga bervariasi. Berikut adalah pembagian pos-pos kerja pada bagian perakitan mini bus 


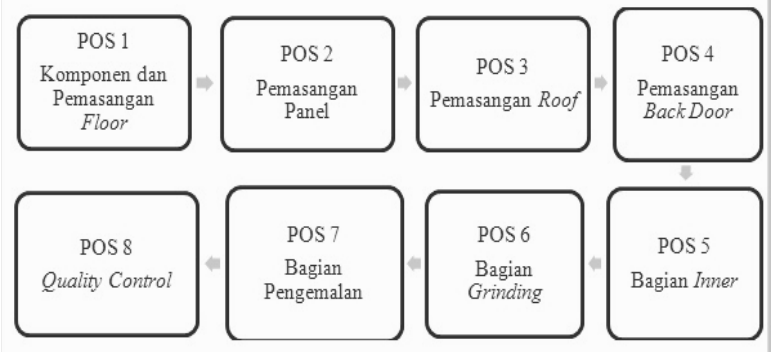

Gambar 1. Sub-Sub Kegiatan pada Bagian Perakitan Mini Bus

Tabel 1. Distribusi Karakteristik Responden Berdasarkan Kelompok Umur

\begin{tabular}{lrc}
\hline \multicolumn{1}{c}{ Kelompok Umur } & $\mathbf{n}$ & $\mathbf{\%}$ \\
\hline 20-24 tahun & 11 & 16,9 \\
25-29 tahun & 23 & 35,4 \\
30-34 tahun & 7 & 10,8 \\
$>34$ tahun & 24 & 36,9 \\
\hline Total & 65 & 100,0 \\
\hline
\end{tabular}

\section{Gambaran Karakteristik Individu Pekerja Bagian Perakitan Mini Bus}

Responden yang diteliti sebanyak 65 orang dari seluruh pekerja pada Bagian Perakitan Mini Bus. Seluruh responden berjenis kelamin laki-laki dengan tingkat pendidikan terakhir adalah SMK/SMA. Perusahaan belum pernah melakukan pemeriksaan kesehatan berkala mengenai keluhan dan gangguan terkait MSDs yang dialami pekerja. Gambaran karakteristik responden penelitian pada Tabel 1.

Berdasarkan tabel 1, sebagian besar responden yaitu 24 orang $(36,9 \%)$ termasuk dalam kelompok umur $>34$ tahun dan 23 orang $(35,4 \%)$ tergolong kelompok umur 25-29 tahun. Dari 24 responden yang berusia $>34$ tahun, terdapat 10 orang berusia antara 40-55 tahun, sedangkan 14 orang sisanya berusia antara 35-40 tahun. Semua responden penelitian tergolong usia produktif.

Berdasarkan tabel 2, sebagian besar responden yaitu sebanyak $41,5 \%$ memiliki masa kerja $<5$ tahun. 38,5\% responden memiliki masa kerja $>10$ tahun dan sebagian kecil responden (18\%) memiliki masa kerja 5-10 tahun. Dari 27 orang yang memiliki masa kerja $<5$ tahun, 18 responden sudah bekerja selama 4 tahun, 4 responden bekerja selama 3 tahun dan 5 responden selama 2 tahun.

Berdasarkan tabel 3, sebagian besar responden yaitu sebanyak 37 orang $(56,9 \%)$ tergolong dalam perokok ringan (menghisap rokok $<10$ batang/
Tabel 2. Distribusi Karakteristik Responden Berdasarkan Kelompok Masa Kerja

\begin{tabular}{lcc}
\hline \multicolumn{1}{c}{ Masa Kerja } & n & \% \\
\hline$<5$ tahun & 27 & 41,5 \\
$5-10$ tahun & 13 & 20,0 \\
$>10$ tahun & 25 & 38,5 \\
\hline Total & 65 & 100,0 \\
\hline
\end{tabular}

Tabel 3. Distribusi Karakteristik Responden Berdasarkan Kebiasaan Merokok

\begin{tabular}{lcc}
\hline \multicolumn{1}{c}{ Kelompok Umur } & n & \% \\
\hline 20-24 tahun & 11 & 16,9 \\
25-29 tahun & 23 & 35,4 \\
30-34 tahun & 7 & 10,8 \\
$>34$ tahun & 24 & 36,9 \\
\hline Total & 65 & 100,0 \\
\hline
\end{tabular}

Tabel 4. Distribusi Responden Berdasarkan Iklim Kerja dan Lokasi Pengukurannya

\begin{tabular}{lccc}
\hline $\begin{array}{c}\text { Lokasi } \\
\text { Pengukuran }\end{array}$ & Iklim Kerja & n & \% \\
\hline Sub Komponen & $28,3^{\circ} \mathrm{C}$ & 21 & 32,3 \\
Sub Floor & $28,3^{\circ} \mathrm{C}$ & 10 & 15,4 \\
Sub Panel & $28,1^{\circ} \mathrm{C}$ & 10 & 15,4 \\
Sub Pengemalan & $29,2^{\circ} \mathrm{C}$ & 12 & 18,5 \\
Sub Penghalusan & $29,3^{\circ} \mathrm{C}$ & 12 & 18,5 \\
\hline Total & & 65 & 100,0 \\
\hline
\end{tabular}

hari) dan 17 orang (26,2\%) tidak merokok. 13,8\% responden merupakan perokok sedang (menghisap rokok 10-20 batang/hari) dan sebagian kecil responden sebanyak $3,1 \%$ tergolong dalam perokok berat (menghisap rokok $>20$ batang/hari).

\section{Gambaran Paparan Iklim Kerja berdasarkan Hasil Pengukuran ISBB}

Pengukuran ISBB dilakukan secara langsung pada 5 titik pengukuran dengan menggunakan alat area Heatstress Monitor WBGT Quest Temp 36. 5 titik pengukuran ini ditetapkan berdasarkan lokasi kerja setiap responden penelitian. Gambaran iklim kerja di bagian perakitan mini bus berdasarkan pengukuran ISBB pada Tabel 4.

Iklim kerja tertinggi di bagian perakitan mini bus adalah $29,3{ }^{\circ} \mathrm{C}$ dan yang terendah adalah $28,1^{\circ} \mathrm{C}$. Sebagian besar responden $(32,3 \%)$ terpapar iklim 
Tabel 5. Distribusi Responden Berdasarkan Hasil Penilaian Kuisioner NBM

\begin{tabular}{lrc}
\hline Keluhan MSDs & n & \% \\
\hline Risiko Sedang & 36 & 55,4 \\
Risiko Tinggi & 24 & \\
Risiko Sangat Tinggi & 5 & 7,7 \\
\hline Total & 65 & 100,0 \\
\hline
\end{tabular}

kerja sebesar $28,3^{\circ} \mathrm{C}$ dan pos kerja dengan paparan iklim kerja tertinggi adalah sub bagian penghalusan. Hasil penilaian beban kerja pada semua sub bagian perakitan mini bus adalah sedang dan pengaturan waktu istirahat selama 45 menit untuk 8 jam kerja/ hari.

\section{Gambaran Keluhan MSDs pada Pekerja Bagian Perakitan Mini Bus}

Penilaian keluhan MSDs dengan metode NBM dapat menunjukkan bagian tubuh yang terasa sakit (nyeri, pegal, kaku, kesemutan dan/atau kram). Hasil analisis kuesioner pada 65 responden menunjukkan bahwa bagian tubuh yang paling banyak dikeluhkan sakit/nyeri oleh pekerja adalah leher, punggung, pinggang, bahu kiri dan lengan atas kiri. Berikut adalah gambaran distribusi keluhan MSDs yang dirasakan responden berdasarkan hasil penilaian kuesioner NBM.

Tabel 5 di atas menunjukkan bahwa, sebagian besar pekerja $(55,4 \%)$ mengalami keluhan MSDs yang tingkat risiko sedang dan sebagian besar

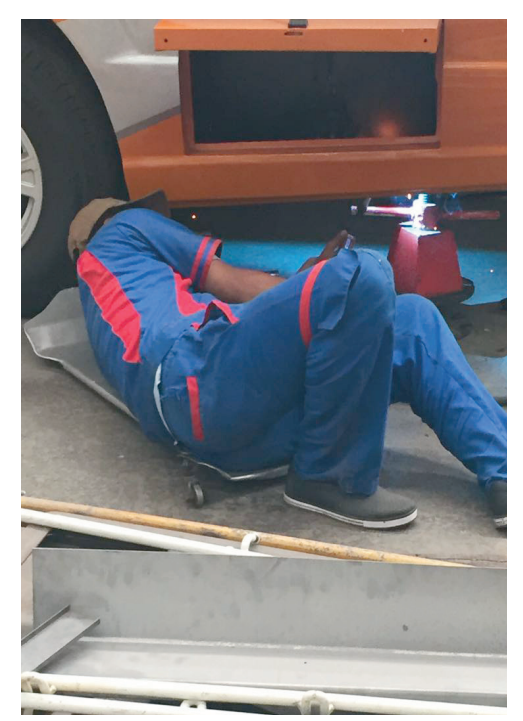

Gambar 1. Contoh Posisi Kerja yang Dapat Menyebabkan Sakit pada Bagian Leher, Bahu dan Lengan Atas Kiri lainnya tergolong risiko tinggi (36,9\%). Tingkat keluhan MSDs yang dirasakan tiap responden bergantung aktivitas kerja pada masing-masing sub bagian. Sebagian besar responden $(53,2 \%)$ mengalami keluhan MSDs pada tingkatan sakit dan agak sakit (41,0\%). Bagian tubuh yang paling banyak dikeluhkan sakit dengan tingkatan sakit sekali oleh pekerja adalah punggung dan pinggang. Berikut ini adalah contoh posisi kerja yang dapat menyebabkan sakit pada bagian leher, bahu dan lengan atas kiri.

Penilaian keluhan MSDs dengan metode NBM tergolong subjektif sehingga keluhan yang dirasakan pekerja bergantung persepsi pekerja tersebut terhadap rasa sakit/nyeri sehingga tingkat keluhan yang sebenarnya dirasakan responden penelitian bisa lebih parah atau ringan dibandingkan hasil yang didapat dari kuisioner NBM.

Berdasarkan tingkat keparahannya, pekerja pada sub bagian komponen lebih sering melakukan pekerjaannya dengan posisi duduk, sebaliknya pada pekerja sub bagian floor, panel, roof, pengemalan dan penghalusan lebih banyak melakukan pekerjaannya dengan posisi berdiri. Posisi kerja berdiri seringkali dilakukan dengan kondisi cukup ekstrem karena pekerja tidak dapat menjangkau objek yang dikerjakan sehingga harus membungkuk atau miring ke kanan/kiri yang menjauhi titik normal tubuh. Berikut adalah contoh posisi kerja yang menyebabkan sakit/nyeri pada bagian punggung dan pinggang.

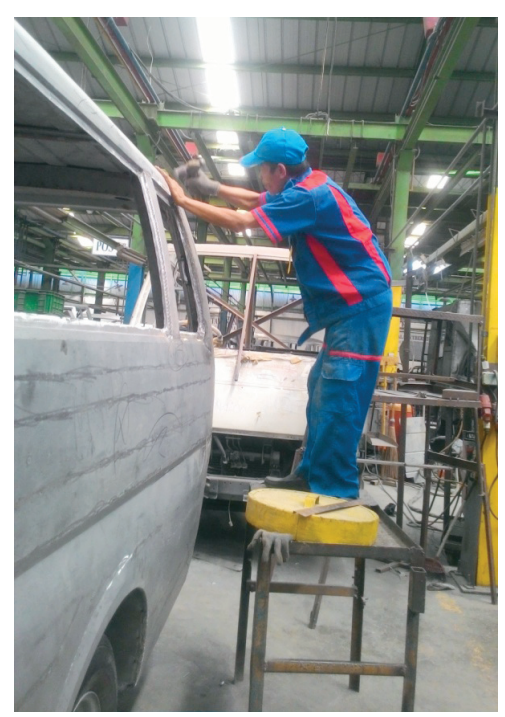

Gambar 2. Contoh Posisi Kerja yang Dapat Menyebabkan Sakit pada Bagian Punggung dan Pinggang 


\section{Hubungan antara Karakteristik Individu dengan Keluhan MSDs}

Uji statistik menggunakan korelasi spearmanrho antara umur dan keluhan MSDs didapatkan bahwa $p$ value $=0,597$ ( $p$ value $>\alpha$ ). Artinya tidak ada hubungan antara umu pekerja dengan keluhan MSDs yang dirasakan. Uji korelasi antara masa kerja dan keluhan MSDs juga didapatkan bahwa $p$ value $=0,332(p$ value $>\alpha)$ yang berarti tidak ada hubungan antara masa kerja responden dengan keluhan MSDs yang dirasakan responden. Uji korelasi antara kebiasaan merokok dan keluhan MSDs juga didapatkan bahwa $p$ value $=0,448$ ( $p$ value $>\alpha$ ) yang berarti tidak ada hubungan antara kebiasaan merokok dengan keluhan MSDs yang dirasakan oleh responden.

\section{Hubungan antara Iklim Kerja dengan Keluhan MSDs}

Hasil uji statistik menggunakan korelasi spearman-rho antara iklim kerja dan keluhan MSDs didapatkan bahwa $p$ value $=0,000$ dengan nilai koefisien korelasinya $=0,730$. Artinya ada hubungan yang signifikan dan kuat antara iklim kerja dengan keluhan MSDs yang dirasakan pekerja, sehingga semakin tinggi paparan iklim kerja di tempat kerja, semakin tinggi tingkat keluhan MSDs pada pekerja.

\section{PEMBAHASAN}

\section{Penilaian Paparan Iklim Kerja dengan Pengukuran ISBB}

Iklim kerja merupakan kombinasi dari suhu kerja, kelembapan udara, kecepatan aliran udara dan suhu radiasi pada suatu tempat kerja. Iklim kerja yang melebihi NAB bisa menimbulkan ketidaknyamanan dan menurunkan kapasitas kerja sehingga menyebabkan penurunan efisiensi serta produktivitas kerja (Guo et al., 1995).

Berdasarkan hasil pengukuran ISBB, Iklim kerja di bagian perakitan mini bus melebihi NAB yang ditetapkan oleh Permenakertrans RI No 13/ MEN/2011 untuk kategori beban kerja sedang. Cukup tinggi iklim kerja di bagian perakitan mini bus disebabkan oleh tingginya sumber radiasi dari aktivitas pengelasan di dalam ruangan dan kondisi ini diperparah oleh kurang baiknya sistem ventilasi yang ada. Beberapa pos kerja di bagian perakitan mini bus seperti sub bagian lambung/panel, floor, roof, pintu (side-back door), inner dan pengemalan, berhubungan dengan aktivitas pengelasan setiap hari secara berulang selama 8 jam/hari.

Perusahaan telah melakukan beberapa upaya untuk mengurangi dampak yang ditimbulkan oleh paparan iklim kerja yang tinggi di bagian perakitan mini bus seperti penyediaan air minum yang memenuhi kebutuhan semua pekerja (ada \pm 8 tangki air yang berisi 25 liter air minum/tangki) serta pemasangan ventilasi buatan (local exhaust ventilation) yang jumlahnya cukup banyak (sesuai kebutuhan area kerja).

Kondisi atap bangunan yang terlalu tinggi menyebabkan kerja ventilasi buatan tidak maksimal, sehingga perusahaan disarankan untuk mendesain ulang atap bangunan menjadi lebih pendek dan melakukan pemeliharaan berkala terhadap local exhaust ventilation yang tersedia, mengganti model atap bangunan menjadi bertingkat (model atap monitor) sehingga ada celah udara yang berguna sebagai outlet udara panas serta menambah celah-celah ventilasi alami pada bagian dinding bangunan.

\section{Penilaian Keluhan MSDs dengan Metode NBM}

Sebagian besar pekerja yang menjadi responden dalam penelitian ini adalah welder dan berdasarkan hasil penilaian kuesioner NBM, bagian tubuh yang paling banyak dikeluhkan sakit dan/atau nyeri oleh pekerja adalah leher, bahu, punggung, pinggang dan lengan atas. Hasil penelitian ini sejalan dengan hasil penelitian Zulfiqor (2010) pada welder di bagian fabrikasi PT Cartepillar Indonesia, yang menjelaskan bahwa keluhan MSDs pada welder seperti kaku dan/ atau nyeri sering dirasakan pada anggota tubuh bagian leher, bahu dan pinggang.

Keluhan MSDs pada bagian leher, bahu dan lengan atas pada pekerja bagian perakitan mini bus disebabkan karena posisi kerja yang ekstrem seperti : setengah terlentang di bawah body kendaraan yang dirakit ataupun berdiri sambil menjinjit untuk menggapai objek kerja yang terlalu tinggi dalam waktu lama. Keluhan MSDs pada pinggang dan punggung disebabkan karena posisi kerja membungkuk akibat objek kerja yang terlalu pendek, ataupun batang tubuh yang terlalu miring menjauhi titik normalnya saat bekerja.

Menurut Tarwaka (2015), keluhan MSDs pada bagian leher dan bahu terjadi karena pekerja melakukan posisi ekstrem secara berulang yang menekan bagian leher dan bahu selama bekerja, sedangkan keluhan pada pinggang dan punggung muncul akibat postur kerja yang buruk seperti 
bekerja dengan posisi membungkuk atau mengangkat beban yang berat secara berulang (Tarwaka, 2015).

Ruas-ruas tulang yang menekuk ke depan saat bekerja akan menyebabkan otot bekerja lebih keras untuk menopang tulang dan rangka bagian atas sampai kepala sehingga lama kelamaan otot mengalami kelenturan. Jika terjadi secara berulang, otot-otot akan kehilangan kelenturannya secara permanen apabila proses recovery tidak terjadi sempurna akibat lama waktu istirahat yang kurang.

Perusahaan memperbolehkan setiap pekerja bagian perakitan mini bus untuk mengambil waktu istirahat selama 5-10 menit/jam. Namun, karena target produksi yang cukup tinggi, sebagian besar pekerja jarang menggunakan waktu istirahat tersebut untuk beristirahat (tetap bekerja selama 60 menit/ jam).

Diharapkan perusahaan menetapkan waktu istirahat tambahan selama 5-10 menit/jam kerja untuk seluruh pekerja. Waktu istirahat yang dimaksud bukan untuk istirahat dan tidak bekerja tetapi pekerja dapat melakukan rotasi kerja (berganti jenis pekerjaan yang dilakukan di bagian perakitan mini bus) pada pekerjaan lain yang beban kerjanya lebih ringan dan posisi kerjanya juga berbeda. Kondisi ini secara tidak langsung membuat pekerja melakukan peregangan otot (stretching) secara berkala setiap jam.

\section{Analisis Hubungan Umur Pekerja terhadap Keluhan MSDs}

Umur adalah salah satu faktor internal yang dapat mempengaruhi timbulnya keluhan MSDs pada pekerja. Kekuatan maksimal otot dapat terjadi pada saat seseorang berumur 20-29 tahun, dan akan menurun sampai $20 \%$ saat umur sudah mencapai 60 tahun (Batti et al., 1989). Menurut Bridger (2003), semakin tua seseorang semakin tinggi risiko orang tersebut mengalami penurunan elastisitas tulang, sehingga memicu timbulnya gejala MSDs. Proses degenerasi pada tulang sejalan dengan pertambahan umur dan kondisi ini akan dimulai saat seseorang berumur 30 tahun. Degenerasi yang terjadi berupa kerusakan jaringan, pergantian jaringan menjadi jaringan parut dan pengurangan cairan. Kondisi inilah yang menyebabkan stabilitas otot dan tulang menjadi berkurang.

Hasil penelitian menunjukkan bahwa semua kelompok umur pekerja mengalami keluhan MSDs dengan tingkat risiko yang bervariasi. Keluhan
MSDs risiko sedang lebih banyak dialami pekerja yang berumur 25-29 tahun, sedangkan keluhan MSDs risiko tinggi lebih banyak dialami pekerja yang berumur $>34$ tahun. Kondisi ini sejalan dengan pendapat Santoso (2004), bahwa nyeri punggung dan otot bisa mulai dirasakan pada usia 20-40 tahun yang kemungkinan disebabkan oleh beban statik pada otot saat bekerja ataupun terjadinya osteoporosis.

Uji statistik antara umur dan keluhan MSDs pada responden, didapatkan bahwa $p>0,05$ yang berarti bahwa tidak ada hubungan antara umur pekerja dengan keluhan MSDs yang dirasakan. Hasil ini sejalan dengan penelitian Nuryaningtyas (2014) yang menjelaskan bahwa tidak ada hubungan yang signifikan antara umur dengan keluhan MSDs pada perawat RSUD Bhakti Dharma Husada Surabaya. Penelitian ini juga sejalan pendapat Mardiman (2001) yang menyatakan bahwa nyeri pada otot bisa terjadi pada pekerja usia muda, dan sebagian besar menyerang usia-usia produktif. Usia-usia produktif yang dimaksud adalah pekerja yang berumur antara 15-64 tahun (ILO, 2013). Semua pekerja yang menjadi responden dalam penelitian ini memiliki rentang usia antara 20-55 tahun sehingga tergolong dalam usia-usia produktif dan berisiko terhadap keluhan MSDs.

Pekerja yang berumur $<30$ tahun juga mengalami keluhan MSDs karena faktor penyebab keluhan MSDs tidak hanya dipengaruhi oleh umur seseorang, tetapi juga faktor pekerjaan dan lingkungan. Faktor pekerjaan adalah faktor-faktor yang terkait langsung dengan keluhan MSDs (Tarwaka, 2015). Pekerja yang berusia muda biasanya mendapat pekerjaan dengan beban fisik yang lebih berat dibandingkan dengan pekerja yang berusia tua. Beban fisik yang berat seringkali memaksa pekerja mengambil posisi-posisi kerja yang tidak ergonomis dan/atau melakukan pengerahan otot yang berlebihan. Jika terjadi terus menerus dalam waktu yang lama, keluhan MSDs pada pekerja muda akan lebih cepat terjadi.

Upaya yang dapat dilakukan perusahaan untuk mengurangi risiko terjadinya keluhan MSDs pada pekerja yang berusia muda ataupun tua adalah peningkatan pengetahuan seluruh pekerja tentang pencegahan-pencegahan risiko ergonomi berdasarkan aktivitas kerja masing-masing. Sosialisasi dapat dilakukan pada saat briefing sebelum kerja atau melalui pelatihan rutin K3L yang dilakukan setiap 1 bulan sekali oleh manajemen. 


\section{Analisis Hubungan Masa Kerja terhadap Keluhan MSDs}

Masa kerja adalah faktor kombinasi yang berkontribusi terhadap keluhan MSDs. Faktor kombinasi berarti bahwa masa kerja tidak bisa secara langsung menimbulkan MSDs tapi harus disertai paparan faktor-faktor lain khususnya yang berasal dari pekerjaan (Tarwaka, 2015). Masa kerja dapat berpengaruh dominan apabila jenis pekerjaan yang dilakukan sama dengan penggunaan otot yang sama oleh pekerja (Nuryaningtyas, 2014). Sedangkan pada penelitian ini, jenis pekerjaan yang dilakukan tiap responden bergantung pos kerja masing-masing, sehingga penggunaan otot dan pengerahan tenaga yang dilakukan berbeda-beda sehingga faktor masa kerja tidak berpengaruh dominan pada keluhan MSDs.

Uji statistik korelasi spearman-rho menunjukkan $p>0,05$ yang berarti bahwa tidak ada hubungan antara masa kerja dengan keluhan MSDs yang dirasakan pekerja. Hasil ini sejalan dengan penelitian Bukhori (2010) dan Fuady (2013), yang menjelaskan bahwa tidak ada hubungan signifikan antara masa kerja dengan keluhan MSDs pada pekerja. Tidak adanya hubungan antara masa kerja dan keluhan MSDs dapat disebabkan karena proses adaptasi terhadap pekerjaan. Pekerja baru atau yang bekerja $<5$ tahun kemungkinan besar belum bisa beradaptasi dengan baik terhadap pekerjaan yang dilakukan sehingga melakukan pengerahan tenaga dan penggunaan otot yang berlebihan pada saat bekerja.

Upaya yang dapat dilakukan perusahaan untuk mengurangi risiko terjadinya keluhan MSDs adalah penetapan jeda waktu per jam kerja untuk pekerja berpindah posisi kerja (untuk sejenak) pada jenis pekerjaan dengan posisi kerja yang berbeda dan beban kerja yang lebih ringan. Pekerja yang lebih banyak bekerja dengan posisi kerja berdiri berpindah kerja sejenak pada sub bagian yang jenis pekerjaannya lebih banyak dilakukan dengan posisi duduk begitupun sebaliknya.

\section{Analisis Hubungan Kebiasaan Merokok terhadap Keluhan MSDs}

Mekanisme merokok dengan kejadian MSDs adalah nikotin yang masuk ke dalam tubuh bisa mempengaruhi berkurangnya aliran darah ke jaringan, menyebabkan kekurangan kandungan mineral pada tulang sehingga menyebabkan nyeri akibat keretakan tulang (NIOSH, 1997). Beberapa penelitian menunjukkan bahwa perokok berisiko mengalami gangguan MSDs daripada bukan perokok. Meningkatnya keluhan otot berkaitan erat dengan lama dan tingkat kebiasaan merokok. Semakin lama dan tinggi frekuensi merokok seseorang, semakin tinggi juga keluhan otot yang dirasakan (Pamer et al, 2003).

Hasil penelitian menunjukkan bahwa semua pekerja baik yang bukan perokok, dan perokok (ringan, sedang, berat) merasakan keluhan MSDs dengan tingkat risiko yang bervariasi. Sebagian besar pekerja yang mengalami keluhan MSDs risiko sedang dan tinggi adalah perokok ringan (jumlah rokok $<10$ batang/hari), sedangkan yang mengalami MSDs risiko tinggi adalah pekerja yang tidak merokok.

Uji statistik korelasi spearman-rho menunjukkan bahwa $p>0,05$ yang berarti bahwa tidak ada hubungan antara kebiasaan merokok dengan keluhan MSDs yang dirasakan pekerja. Hasil ini sejalan dengan penelitian yang dilakukan oleh Bukhori (2010) dan Mutiah (2013), yang menyatakan bahwa tidak hubungan yang signifikan antara kebiasaan merokok pekerja dengan keluhan MSDs yang dirasakan.

Merokok adalah salah satu faktor internal yang dapat meningkatkan risiko terjadinya keluhan MSDs, tetapi dampak yang ditimbulkan rokok bersifat kronik sehingga ada kemungkinan saat penelitian dilakukan, efek yang ditimbulkan dari merokok belum terlihat pada pekerja. Upaya pencegahan yang bisa dilakukan terhadap dampak negatif dari merokok pada pekerja adalah melakukan senam sehat setiap hari sebelum pekerjaan dimulai selama 5-10 menit. Perusahaan juga dapat menetapkan peraturan dan sanksi terkait larangan merokok saat bekerja sehingga secara tidak langsung dapat membatasi konsumsi rokok per hari pada pekerja.

\section{Analisis Hubungan antara Iklim Kerja terhadap Keluhan MSDs pada Pekerja}

MSDs terjadi sebagai akibat dari kombinasi berbagai faktor yaitu faktor pekerja, pekerjaan dan lingkungan. Faktor lingkungan seperti paparan suhu yang berlebihan (baik dingin ataupun panas) akan menurunkan kelincahan, kekuatan dan kepekaan pekerja sehingga gerakan yang dihasilkan lebih lamban serta sulit bergerak yang akan disertai dengan penurunan kekuatan otot (Tarwaka, 2015).

Hasil uji statistik menunjukkan bahwa ada hubungan yang kuat antara posisi kerja dengan keluhan MSDs yang dialami pekerja. Artinya, 
semakin tinggi paparan iklim kerja semakin tinggi juga risiko keluhan MSDs pada pekerja. Penelitian ini sejalan dengan penelitian Bang et al (2015) yang menjelaskan bahwa paparan panas yang berlebihan dapat meningkatkan risiko keluhan MSDs secara signifikan. Paparan panas yang berlebihan menyebabkan air dan garam-garam mineral yang dibutuhkan oleh otot banyak terlarut dalam keringat yang keluar sehingga menyebabkan terjadinya ketidakseimbangan elektrolit dan kram otot. Kondisi ini akan semakin parah apabila suhu lingkungan tempat kerja adalah panas lembab.

Berdasarkan hasil pengukuran ISBB, iklim kerja di bagian perakitan mini bus tergolong panas lembab karena ISBB yang dihasilkan cukup tinggi (melebihi NAB) sementara tingkat kelembapan relatif-nya cukup tinggi (berkisar antara 60-70\%). Kondisi ini lebih berisiko menimbulkan kelelahan pada pekerja

Paparan iklim kerja yang melebihi NAB dan risiko terjadinya keluhan MSDs pada pekerja menuntut perusahaan untuk menetapkan upayaupaya perbaikan yang tepat dan cepat untuk segera diaplikasikan. Berdasarkan ketentuan Permankertrans RI No. 13/MEN/X/2011, waktu yang kerja yang diijinkan untuk pekerja bagian perakitan mini bus bekerja di sub bagian kerjanya masing-masing adalah 45-60 menit per jam, tetapi karena risiko MSDs pekerja tergolong sedang maka disarankan agar pengaturan waktu kerja per jamnya adalah sebagai berikut: 45 menit bekerja di sub bagian masing-masing (sesuai dengan job description) dan 15 menit di sub bagian lain yang beban kerjanya lebih ringan dengan posisi kerja yang berbeda sehingga membantu proses peregangan otot pekerja secara berkala.

\section{SIMPULAN}

Sebagian besar responden penelitian memiliki karakteristik yaitu berumur $>34$ tahun, masa kerja $<$ 5 tahun dan tergolong perokok ringan. Paparan iklim kerja pada bagian perakitan mini bus melebihi NAB berdasarkan Permenakertrans RI No. 13 tahun 2012 untuk kategori beban kerja sedang

Berdasarkan hasil penilaian kuesioner NBM, sebagian besar pekerja mengalami keluhan MSDs dengan tingkat risiko sedang dan anggota tubuh yang paling banyak dikeluhkan sakit/nyeri oleh pekerja adalah leher, bahu, lengan atas, punggung dan pinggang.

Tidak ada hubungan karakteristik individu (umur, masa kerja dan kebiasaan merokok) dengan keluhan MSDs yang dirasakan pekerja. Ada hubungan yang kuat dan signifikan antara paparan iklim kerja dan keluhan MSDs yang dirasakan pekerja sehingga semakin tinggi risiko posisi kerja dan paparan iklim kerja, semakin tinggi juga tingkat keluhan MSDs pada pekerja.

Perusahaan disarankan untuk meningkatkan pengetahuan seluruh pekerja tentang pencegahanpencegahan risiko ergonomi berdasarkan aktivitas kerja masing-masing dan mengurangi dampak kesehatan dari kebiasaan merokok pekerja melalui senam sehat secara rutin setiap hari. Peningkatan pengetahuan dapat dilakukan melalui sosialisasi saat briefing sebelum kerja dan senam sehat dapat dilakukan selama 5-10 menit/hari sebelum briefing kerja dimulai.

Perusahaan diharapkan melakukan pengaturan ulang waktu kerja per jamnya untuk seluruh pekerja di bagian perakitan mini bus dengan ketentuan sebagai berikut: 45 menit bekerja di sub bagian masing-masing (sesuai dengan job description) dan 15 menit di sub bagian lain yang beban kerjanya lebih ringan dengan posisi kerja yang berbeda sehingga dapat membantu proses peregangan otot pekerja secara berkala.

Tindak lanjut terhadap hasil penelitian ini juga diperlukan untuk memastikan kebenaran gangguan MSDs yang dialami pekerja, sehingga diharapkan akan ada penelitian lebih lanjut dari peneliti lain yang dapat memastikan gangguan MSDs pada pekerja melalui pemeriksaan klinis (penilaian objektif) agar dapat dilakukan upayaupaya pengobatan dan pencegahan yang sesuai pada pekerja.

\section{DAFTAR PUSTAKA}

Bang, B.E., Aasmoe, L., Aardal, L., Egeness, C., Espejord, I., Kramvik, E., Andorsen, J.S., et al. 2005. Feeling Cold at Work Increases the Risk of Symptoms from Muscles, Skin, and Airways in the Seafood Industry Workers. American Journal of Industrial Medicine : 47 (1):65-71.

Battie, M.C., Bigos, S.J., Fisher, L.D, Hansson, T.H., Jones, M.E., Worthly, M.D. 1989. Isomateric Lifting as a Strength Predictor of Industrial Back Pain. Ergonomics. Spine, 14(8): 851-856.

Bridger, R.S. 2003. Introduction to Ergonomics (Second edition). London: Tailor and Francis Group.

Chaffin, D.B. 1979. Manual Material Handling the Cause of overexertion Injury and Illness in 
Industry. Journal of Environmental Pathology and Toxicology, 2(5): 67-73. Ex: 26-1489.

Ellyana, R.N. 2014. Analisis Risiko Postur Kerja pada Pekerjaan Angkat Angkut dengan Metode OWAS terhadap Risiko Keluhan MSDs (Musculoskeletal Disorders) pada Kuli Panggul di Pasar Bunder Sragen. Skripsi. Jurusan Kesehatan Masyarakat FIK Universitas Muhammadiyah Surakarta.

European Agency for Safety and Health at Work. 2010. Occupational Safety in Figures: WMSDs (Work-Related Musculosceletal Disorder) in the $E U$. Luxemburg: Official Publications of the European Communities.

Fuady, A.R. 2013.Faktor-Faktor yang Berhubungan dengan MSDs (Musculoskeletal Disoders) pada Pengrajin Sepatu di Perkampungan Industri Kecil (PIK) Penggilingan Kecamatan Cakung. Skripsi. Fakultas Kedokteran dan Ilmu Kesehatan Universitas Islam Negeri Syarif Hidayatullah Jakarta.

Fausiyah, K. 2016. Paparan Intensitas Kebisingan dan Upaya Pengendalian pada Bagian Perakitan Mini Bus di PT Mekar Armada Jaya Magelang. Laporan Magang. Fakultas Kesehatan Masyarakat Universitas Airlangga Surabaya.

Guo, H., Tanaka, S., Cameroon, L.L., Seligman, P.J., Behrens, V.J., Ger, J., et al. 1995.Back Pain among Workers in the United States: National Estimates and Workers at high Risk. American Journal of Industrial Medicine. 28(5): 591-602.

Hales, T.R., Sauter, S.L., Peterson, M.R., Fine, L.J., Putz-Anderson, V., Schleifer, L.R., et al. 1994. MSDs among Visual Display Terminal Users in a Telecomunications Company. Ergonomics. Vol. 37, No. 10, pp. 1603-1621.

Hignett, S., Lyn M.A. 2000. Technical : REBA (Rapid Entire Body Assessment), Applied Ergonomics. Cornell University of Ergonimics. Available at http://www.REBA.cutools.htm.

Humantech. 2003. Applied of Ergonomics Training Manual. Barkeley Australia: Humantech Inc.

International Labour Organization. 2013. The Prevention of Occupational Disease. Geneva: International Labour Organization.

Mardiman,S. 2001. Modulasi Nyeri dan Mekanisme Pengurangan Nyeri dengan Modalitas Fisioterapi. Modul Pelatihan Penatalaksanaan Fisioterapi Komprehensif pada Nyeri. Surakarta: Universitas Negeri Sebelas Maret.
Mutiah, A. 2013. Analisis Tingkat Risiko Musculoskeletal Disorders (MSDs) dengan The Brief Survey dan karakteristik individu terhadap Keluhan MSDs Pembuat Wajan di Desa Cepogo Boyolali. Skripsi. Fakultas Kesehatan Masyarakat Universitas Diponegoro.

National Institute for Occupational Safety and Health. 1997. Musculoskeletal Disorders and Workplace Factors: a Critical Review of Epidemiologic Evidence for Work-Related MSDs of the Neck, Upper Extremity and Low Back.U.S Department of Health and Human Services, Public Health Services for Disease Control and Preventions.

National Institute for Occupational Safety and Health. 2007. Ergonomic Guidelines for Manual Handling. DHHS (NIOSH) Publication No. 2007131. Columbia : NIOSH/CDC.

Nurfajri, P. 2015. Faktor-Faktor yang Berhubungan dengan keluhan MSDs pada Pekerja Laundry di Kelurahan Muktiharjo Kidul Semarang.Tugas Akhir. Universitas Dian Nuswantoro Semarang.

Nuryaningtyas, B.M. 2014. Analisis Tingkat Risiko MSDs dengan RULA dan Karakteristik Individu terhadap Keluhan MSDs. Skripsi. Universitas Airlangga Surabaya.

Oborne, D.J. 1995. Ergonomics at Work: Human Factors in Design and Development. England: John Wiley and Sohn Ltd.

Pangaribuan, D.M. 2009. Analisa Postur Kerja dengan Metode RULA pada pegawai Bagian Pelayanan Perpustakaan USU Medan. Skripsi. Medan : Universitas Sumatra Utara.

Palmer, K., Syddall, H., Cooper, C., Coggon, D. 2003. Smoking and Musculosceletal Disorders : Findings from a British National Survey. Journal of Sound Vibration. Ann Rheum Dis v.62 (1).

Peraturan Menteri Tenaga Kerja dan Transmigrasi Republik Indonesia Nomor. 13/MEN/X/2011 tentang Nilai Ambang Batas Faktor Fisika dan Kimia di Tempat Kerja. Jakarta.

Sanders, M. J. 2004. Ergonomics and the Management of Musculoskeletal Disorders (Second Edition). USA: Elsevier.

Santoso, G. 2004. Ergonomi: Manusia, Peralatan dan Lingkungan. Jakarta: Prestasi Pustaka Publisher.

Stanton, N.A. 2005. Handbook of Human Factors and Ergonomics Methods. Florida: CRC Press.

Suma'mur. 2009. Higiene Perusahaan dan Kesehatan Kerja. Jakarta: PT Toko Gunung Agung. 
Susila, I.G.N. 2002. Muskuloskeletal Disorders. Majalah Kedokteran Udayana. 33 (116): 78. Fakultas Kedokteran Udayana.

Tarwaka. 2015. Ergonomi Industri: Dasar-dasar Pengetahuan Ergonomi dan Aplikasi di Tempat Kerja. Edisi Ketiga. Surakarta: Harapan Press.
Zulfiqor, M. T. 2010. Faktor-Faktor yang Berhubungan dengan Keluhan MSDs pada Welder di Bagian Fabrikasi PT Cartepillar Indonesia. Skripsi. Program Studi Kesehatan Masyarakat, Universitas Islam Negeri Syarif Hidayatullah Jakarta 